\title{
Genetic Diversity in Dengue Mosquito, Aedes aegypti (Diptera: Culicidae) from Amazon Region: Comparative Analysis with Isozymes and RAPD Loci
}

\author{
Joselita Maria Mendes dos Santos ${ }^{*}, 1,2$, Elmary C. Fraga ${ }^{3}$, Juracy F. Maia ${ }^{1}$ and Wanderli P. Tadei ${ }^{1,2}$

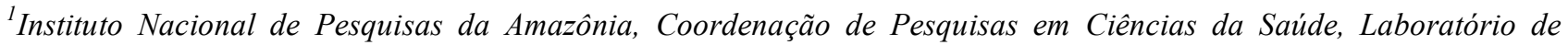 \\ Malária e Dengue, Manaus, AM, Brazil \\ ${ }^{2}$ Universidade do Estado do Amazonas, Manaus, AM, Brazil \\ ${ }^{3}$ Universidade Estadual do Maranhão, Departamento de Biologia, Caxias, Maranhão, Brazil
}

\begin{abstract}
Four populations of Aedes aegypti from Manaus were studied, using allozymes and RAPD loci, to determine intra- and interpopulation genetic variability and differentiation and to compare genetic structure parameters assessed with both markers. Five RAPD primers produced 52 polymorphic fragments, whereas only seven of 18 isozyme loci were polymorphic. The population from Praça 14 was the most polymorphic $(\mathrm{P}=94.23 \%$ and $\mathrm{P}=55.6 \%)$; while those from Coroado ( $\mathrm{P}=82.69 \%$ and $\mathrm{P}=44.40 \%)$ and from Cidade Nova $(\mathrm{P}=84.61 \%$ and $\mathrm{P}=44.40 \%)$ were the least polymorphic, for both RAPD and isozymes respectively. The observed heterozygosity was higher between populations $(\mathrm{Ho}=0.33-$ $0.38)$ as assessed by RAPD. Wright's $F$ statistics showed an $F_{\text {is }}$ value higher than $F_{\text {st }}\left(F_{\text {is }}=0.164>F_{\text {st }}=0.048\right)$. AMOVA indicated that $95.12 \%$ of the genetic variability is intrapopulational. Even so, both of the genetic markers evaluated showed a relatively high gene flow $\left(\left(\mathrm{N}_{\mathrm{m}}=15.15\right)\right.$, and possibly are still random couplings, although the $\mathrm{F}_{\text {is }}$ value was not low. The genetic distance between populations was similarly low for both markers: RAPD $(0.012-0.016)$ and Isozymes $(0.003-0.016)$. These results show that as assessed by both markers, the populations are genetically similar, and that isozymes (codominant) are the most efficient to detect the population genetic structure. Although isozymes revealed less genetic diversity than RAPDs, the estimated levels of genetic distance were identical.
\end{abstract}

Keywords: Population genetics, isozymes, RAPD, dengue vector, Amazonas.

\section{INTRODUCTION}

Aedes (Stegomyia) aegypti Linnaeus is the main vector of yellow-fever virus and of four serotypes of dengue virus and dengue hemorrhagic fever. This mosquito originated in the Old World, probably from the Ethiopian region, and was originally described in Egypt [1]. The species currently has an almost cosmotropical distribution.

Aedes aegypti was reintroduced into Brazil in 1967 and has now infested the entire country [2]. In recent years, dengue cases in Brazil have increased, and dengue fever has become one of the major public-health problems; the number of cases reported in $2007(559,954)$ represents an increase of more than $100 \%$ since 2005 (248,189 cases) [3]. In Amazonas, Ae aegypti was detected in 1996 in the city of Manaus, and today high population rates of this mosquito have been recorded, indicating the magnitude of the problem in the region $[4,5]$. Unfortunately, the situation has worsened in recent years, especially due to the increasing number of cases of dengue hemorrhagic fever.

The epidemiological importance and the ease of laboratory manipulation of Ae. aegypti have facilitated studies on

*Address correspondence to this author at the Instituto Nacional de Pesquisas da Amazônia, Laboratório de Malária e Dengue, P.O. Box 478, Manaus, Amazonas, Brazil; Tel: +559236433062; Fax: +559236433061; E-mail: jsantos@inpa.gov.br its population genetics and molecular biology [5-13]. Many markers have been used in studies on genetic variability and differentiation, in an attempt to quantify and explain this variability, in terms of its origin, maintenance, and importance to evolution. In addition, different factors may contribute to the gene action that leads to the development of differentiated characteristics with respect to vector competence, resistance to insecticides, and ecological adaptation. Knowledge of the genetic structure of these populations may contribute to the development of control programs for this vector.

The isozyme loci segregate as codominant alleles and can therefore be used for the Hardy-Weinberg equilibrium test. So, through the analysis of the estimated intra- and interpopulation genetic variability and differentiation, valuable information is obtained to determine strategies for mosquito control. RAPD-PCR (Random Amplified Polymorphic DNA - Polymerase Chain Reaction) markers, which use only an arbitrary primer and amplify unknown regions of the DNA molecule, are also useful to determine genetic variability and to identify cryptic species in Culicidae. Nonetheless, they are not applicable to the Hardy-Weinberg equilibrium test [14].

In the present investigation, four populations of $A e$. aegypti from Manaus were studied with the aim of estimating the genetic variability and differentiation, by comparing the genetic structure parameters between RAPD (dominant) and Isozyme (codominant) loci. 


\section{MATERIAL AND METHODS}

\section{Sample Origin and Collection}

Larvae and pupae of Ae. aegypti were collected in four districts of the municipality of Manaus: Praça 14 (South), Cidade Nova (North), Coroado (East), and Compensa (West), 10 to $20 \mathrm{~km}$ distant from each other, during the year 1999. The mosquitoes were transported to the insectarium and kept until the adults emerged, which were identified based on Consoli \& Lourenço-de-Oliveira 1994 [1]. Males were fed with a $10 \%$ saccharose solution, and females with hamster blood (Mesocricetus auratus Waterhouse). After mating, females were isolated to obtain individual oviposition. Hatched larvae were maintained until the 4th instar and a small part until the adult stage, according to Santos et al. (1981) [15], and frozen at $-70^{\circ} \mathrm{C}$.

\section{Isozymes}

Eighteen enzyme loci (EST3, EST4, EST5, EST6, LAP1, LAP2, LAP4, LAP5, LAP6, HK1, HK2, ME, MDH, IDH, 6$P G D H, \alpha-G P D H, P G I$, and $P G M)$ were analyzed in $4^{\text {th }}$ instar larvae, individually homogenized, three per egg clutch, except for $\alpha-G P D H$, where adults were used, for a total of 90 individuals per enzyme system/population. Horizontal electrophoresis was used in a gel-starch solution of $12.5 \%$ and a starch-agarose of $2 \%$ and $1 \%$, respectively. Buffer systems and stain solutions were based on Steiner \& Joslyn 1979 [16] and on Lima \& Contel 1990 [17].

\section{RAPD}

One larva from each egg clutch, for a total of approximately 30 individuals per population, was used for the detection of DNA polymorphic fragments. DNA extraction and amplification reactions were carried out according to Williams et al. 1990 [18], using the following oligonucleotides (OPERON): OPA04 (5'-AATCGGGCTG-3'), OPA07 (5'-GAAACGGGTG -3'), OPA08 (5'-GTGACGTAGG$\left.3^{\prime}\right)$, OPA18 (5'-AGGTGACCGT-3'), and OPA20 (5'GTTGCGATCC-3'). The amplification reaction was carried out with a total volume of $25 \mu \mathrm{l}$, containing $1 \mu \mathrm{l}$ of DNA (10 $\mathrm{ng} / \mu \mathrm{l}), 2.5 \mathrm{U}$ Platinum Taq DNA polymerase (Invitrogen), $2.5 \mu \mathrm{l}$ buffer reaction $10 \mathrm{X}, 1.5 \mu \mathrm{l} \mathrm{MgCl}_{2}(50 \mathrm{mM}), 2.5 \mu \mathrm{l}$ dNTP $(5 \mu \mathrm{M}), 14.7 \mu \mathrm{l}$ Milli-Q water, and $2.5 \mu \mathrm{l}$ of a single initiator (Operon Technologies Inc., Alameda, CA $/ 5 \mu \mathrm{M}$ ). Amplification proceeded through 45 cycles at $94^{\circ} \mathrm{C}$ for 1 $\min , 36^{\circ} \mathrm{C}$ for $1 \mathrm{~min}$, and $72^{\circ} \mathrm{C}$ for $2 \mathrm{~min}$, followed by one final extension step at $72^{\circ} \mathrm{C}$ for $7 \mathrm{~min}$. The PCR products were analyzed by electrophoresis on $1.5 \%$ agarose gel in ethidium bromide $(5 \mathrm{ng} / \mu \mathrm{L})$, and visualized on an ultraviolet transilluminator.

\section{Statistical Analysis}

For the analysis of population genetic variability with RAPD, the Tools for Population Genetics Analyses Program (TFPGA) was used in the option - Dominant Markers for Diploid Organisms [14]. In this case, each band is assumed to be a locus. The presence of the band represents the dominant genotype, which contains the two genotypes (homozygote and heterozygote); the absence of the band represents the recessive homozygote genotype. In the case of two heterozygote alleles, they are not distinguishable, as an estimate of the allelic frequency is obtained from the square root of the frequency of the observed absent bands. In this case it is assumed that the estimated allelic frequencies are in Hardy-Weinberg equilibrium. This essentially means that the inbreeding coefficients $\mathrm{f}$ and $\mathrm{F}$ are equal to 0 and $\theta$, respectively. The inbreeding coefficients $\mathrm{f}$ and $\mathrm{F}$ correspond to Wright's $F_{\text {is }}$ and $F_{\text {it }}$, respectively, while theta corresponds to $F_{\text {st }}$ estimates $[19,20]$. For the isozyme analysis, the BIOSYS Program was used [21]. The POPGENE program, version 1.32 [22] was employed for both markers. Effective migration rates $\left(\mathrm{N}_{\mathrm{m}}\right)$ were estimated based on $\mathrm{F}_{\mathrm{st}}$ for isozymes $\left(\mathrm{N}_{\mathrm{m}}=0.25\left(1-\mathrm{F}_{\mathrm{st}}\right) / \mathrm{F}_{\mathrm{st}}\right)$ and $\mathrm{G}_{\mathrm{st}}$ for RAPD $\left(\mathrm{N}_{\mathrm{m}}=0.5(1-\right.$ $\left.\mathrm{G}_{\mathrm{s}} \mathrm{t}\right) / \mathrm{G}_{\mathrm{st}}$ ) inbreeding rates, following McDermott \& McDonald 1993 [23]. The hierarchical analyses of molecular variance (AMOVA) [24] were calculated using the Arlequin program, version 2000 [25], for both the isozyme and the RAPD data. The dendrogram was constructed using the UPGMA method [26]. $F_{\text {is }}, F_{\text {it }}$ and $F_{\text {st }}$ data for isozymes of the POPGENE Program were identical to those of BIOSYS, because they use the Wright's F statistics.

\section{RESULTS}

\section{Levels of Genetic Variability}

For the isozyme analyses, the observed and expected genotype frequencies and chi-square values are shown in Table 1 . Of the 18 loci studied, only seven were polymorphic in the four populations: EST4, EST5, LAP2, LAP5, IDH, $M D H$, and $P G M$. The chi-square values for the majority of the loci were significant in the four populations, indicating an imbalance according to the Hardy-Weinberg model. An exception was found in the population from Compensa, where most of the loci showed non-significant chi-square values $\left(E S T 3-\chi^{2}=0.000\right.$, EST4 $-\chi^{2}=0.006$, LAP2 $-\chi^{2}=$ 0.582 , LAP5 $-\chi^{2}=1.680$, and $I D H-\chi^{2}=0.624$; degrees of freedom $=1$ ). Based on gene-frequency analysis, only $43 \%$ of polymorphic loci were in Hardy-Weinberg equilibrium. Deviation from the Hardy-Weinberg equilibrium was due especially to the excess of homozygotes for the loci EST4, EST5, and LAP2.

Both the Isozyme (Fig. 1) and RAPD (Fig. 2) patterns indicated high genetic diversity. The genetic estimates in the four populations are shown in Tables $\mathbf{2}$ and $\mathbf{3}$. The population from Praça 14 was the most polymorphic $(\mathrm{P}=$ $55.6 \%, \mathrm{P}=94.23 \%$ ) with the highest level of heterozygosity $(\mathrm{Ho}=0.152, \mathrm{H}=0.387)$ on the basis of both isozymes and RAPD loci, respectively. $\mathrm{P}$ and $\mathrm{H}$ values with RAPDs are higher than those obtained with isozymes, because hypervariable loci are frequently revealed by the RAPD procedure.

Based on the RAPD analysis, 52 markers were distinguished in the four populations, ranging in size from 300 to $2072 \mathrm{bp}$. The percentage of polymorphic loci varied from 82.69 to 94.23 . The population from Praça 14 was the most polymorphic, and that from Coroado was the least. Heterozygosity ranged from 0.339 in Coroado to 0.387 in Praça 14. The expected mean heterozygosities within each 
Table 1. Observed and Expected Genotype Frequency at each Polymorphic Locus, and Chi-Square Value for the Determination of the Hardy-Weinberg Equilibrium in Aedes aegypti Populations from Manaus, Based on Isozyme Analyses

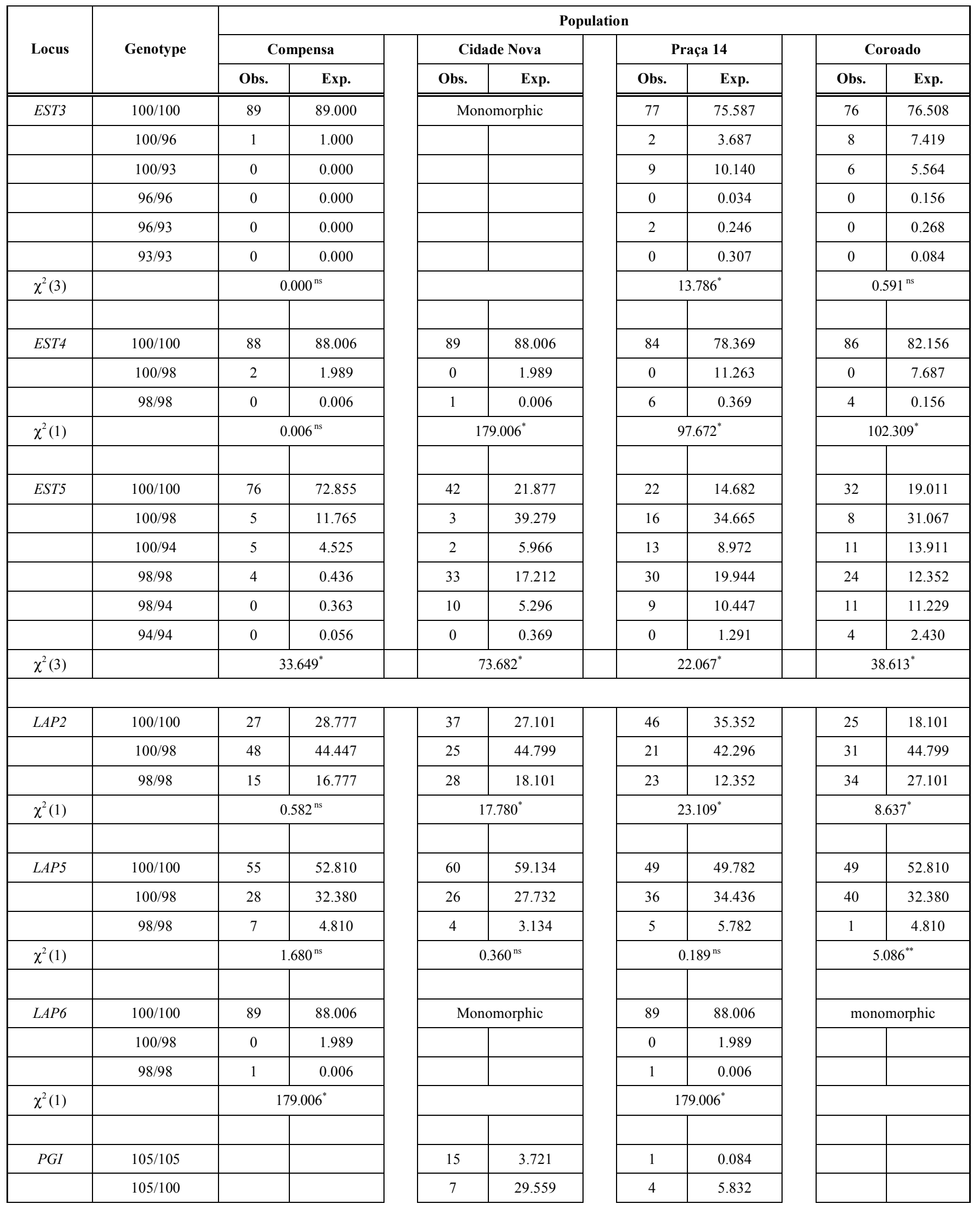


(Table 1) Contd.....

\begin{tabular}{|c|c|c|c|c|c|c|c|c|c|}
\hline \multirow{3}{*}{ Locus } & \multirow{3}{*}{ Genotype } & \multicolumn{8}{|c|}{ Population } \\
\hline & & \multicolumn{2}{|c|}{ Compensa } & \multicolumn{2}{|c|}{ Cidade Nova } & \multicolumn{2}{|c|}{ Praça 14} & \multicolumn{2}{|c|}{ Coroado } \\
\hline & & Obs & $\operatorname{Exp}$ & Obs & $\operatorname{Exp}$ & Obs & $\operatorname{Exp}$ & Obs & $\operatorname{Exp}$ \\
\hline & $100 / 100$ & \multicolumn{2}{|c|}{ monomorphic } & 68 & 56.721 & 85 & 84.084 & \multicolumn{2}{|c|}{ monomorphic } \\
\hline$\chi^{2}(1)$ & & & & \multicolumn{2}{|c|}{$53.653^{*}$} & \multicolumn{2}{|c|}{$10.603^{*}$} & & \\
\hline \multirow[t]{3}{*}{$I D H$} & $110 / 110$ & 7 & 8.603 & 1 & 2.950 & 2 & 3.520 & 4 & 1.413 \\
\hline & $110 / 100$ & 42 & 38.793 & 31 & 27.101 & 32 & 28.961 & 15 & 20.173 \\
\hline & $100 / 100$ & 41 & 42.603 & 58 & 59.950 & 56 & 57.520 & 71 & 68.413 \\
\hline$\chi^{2}(1)$ & & \multicolumn{2}{|c|}{$0.624^{\mathrm{ns}}$} & \multicolumn{2}{|c|}{$1.913^{\mathrm{ns}}$} & \multicolumn{2}{|c|}{$1.015^{\mathrm{ns}}$} & \multicolumn{2}{|c|}{$6.158^{* *}$} \\
\hline \multirow[t]{3}{*}{$M D H 1$} & $110 / 110$ & 16 & 10.911 & 4 & 4.140 & 8 & 7.994 & 15 & 15.922 \\
\hline & $110 / 100$ & 31 & 41.179 & 31 & 30.721 & 38 & 38.011 & 46 & 44.156 \\
\hline & $100 / 100$ & 43 & 37.911 & 55 & 55.140 & 44 & 43.994 & 29 & 29.922 \\
\hline$\chi^{2}(1)$ & & \multicolumn{2}{|c|}{$5.573^{* *}$} & \multicolumn{2}{|c|}{$0.008^{\mathrm{ns}}$} & \multicolumn{2}{|c|}{$0.000^{\mathrm{ns}}$} & \multicolumn{2}{|c|}{$0.159^{\mathrm{ns}}$} \\
\hline \multirow[t]{6}{*}{$P G M$} & $115 / 115$ & 7 & 2.950 & 4 & 2.430 & 1 & 3.927 & 0 & 2.950 \\
\hline & $115 / 105$ & 1 & 1.659 & 6 & 4.190 & 4 & 7.006 & 6 & 5.531 \\
\hline & $115 / 100$ & 18 & 25.441 & 16 & 20.950 & 32 & 23.140 & 27 & 21.570 \\
\hline & $105 / 105$ & 0 & 0.201 & 0 & 1.676 & 0 & 2.950 & 1 & 2.430 \\
\hline & $105 / 100$ & 8 & 6.939 & 19 & 17.458 & 29 & 20.095 & 22 & 19.609 \\
\hline & $100 / 100$ & 56 & 52.810 & 45 & 43.296 & 24 & 32.883 & 34 & 37.911 \\
\hline$\chi^{2}(3)$ & & \multicolumn{2}{|c|}{$8.556^{* *}$} & \multicolumn{2}{|c|}{$4.845^{\mathrm{ns}}$} & \multicolumn{2}{|c|}{$16.160^{*}$} & \multicolumn{2}{|c|}{$5.893^{\mathrm{ns}}$} \\
\hline
\end{tabular}

$\chi^{2}-$ chi-square/Hardy-Weinberg equilibrium

()$=$ degrees of freedom

$*=\mathrm{P}<0.01 ; * *=\mathrm{P}<0.05 ; \mathrm{ns}=$ not significant

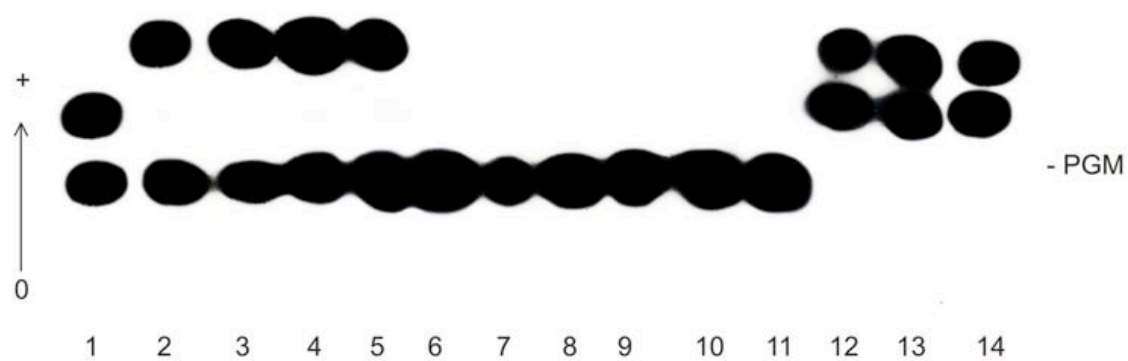

Fig. (1). Starch gel electrophoresis Phosphoglycomutase isoenzymatic profiles for 4th-instar larvae of Aedes aegypti populations from Manaus. Samples: 1 to 3 (Praça 14); 4 to 7 (Coroado); 8 to 10 (Compensa); and 11 to 14 (Cidade Nova). TEEM buffer system, pH 7.4.

population and in the total population were also higher $(\mathrm{Hs}=$ $0.3600 ; \mathrm{Ht}=0.3719$, respectively), reflecting high genetic diversity among the populations $\left(\mathrm{h} *=0.162^{\mathrm{i}}\right.$, $\left.\mathrm{h} *=0.372^{\mathrm{r}}\right)$ (Table 3).

\section{Population Genetic Structure}

The analysis of population structure with RAPD and isozyme loci is presented in Table 4. For isozymes, the Wright's $F$ statistics showed a mean value relative to $F_{\text {is }}$ higher than for $\mathrm{F}_{\text {st }}(0.164>0.041)$. Higher $\mathrm{F}_{\text {is }}$ values compared with $\mathrm{F}_{\text {st }}$ were found in loci LAP6, EST 4, and PGI with $1.000,0.912$, and 0.687 respectively, suggesting intrapopulation differentiation. However, for RAPD, the coefficient of genetic differentiation based on $\mathrm{G}_{\text {st }}$ was lower (0.032). A still lower value was observed when we analyzed the genetic structure based on the $\theta$ method to verify the inbreeding coefficients among populations $(\theta=0.025)$, with the "bootstrapping" rate of consistency for 1000 replications 


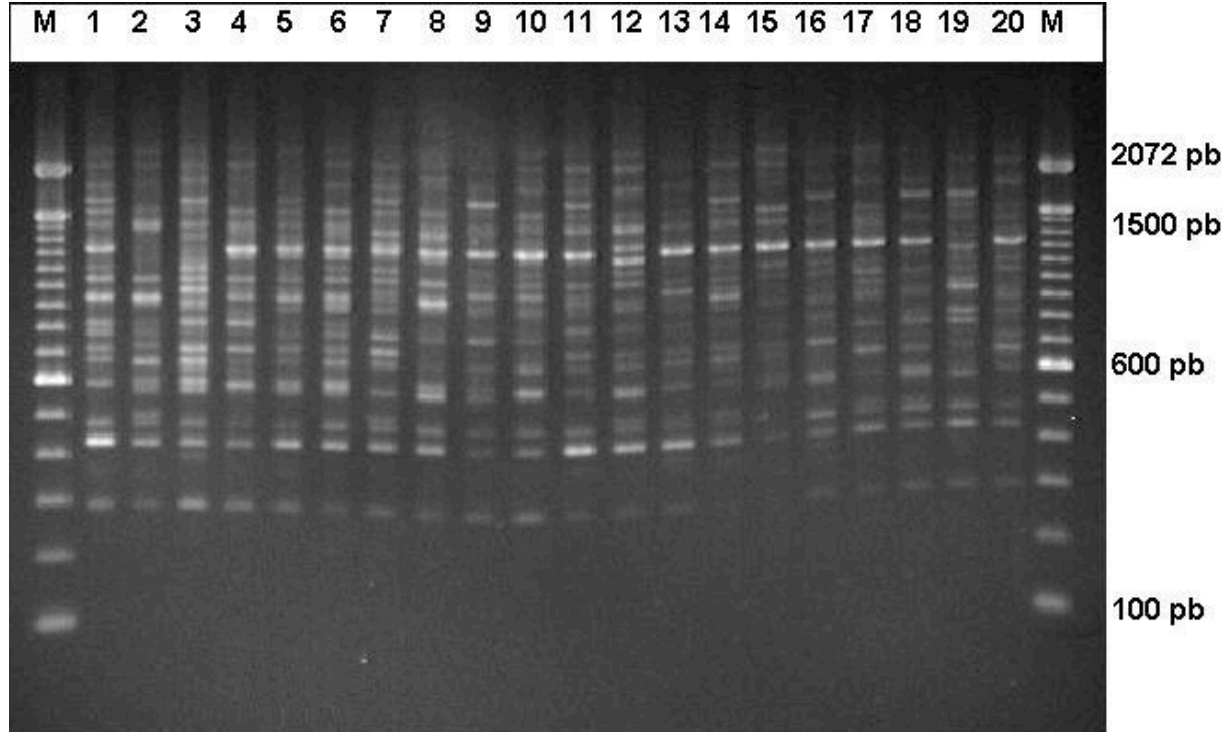

Fig. (2). RAPD profiles for 4th-instar larvae of Aedes aegypti populations from Manaus. Primer OPA 08. Samples: 1 to 5 (Coroado), 6 to 10 (Compensa), 11 to 15 (Cidade Nova), and 16 to 20 (Praça 14). M= 100 bp DNA Ladder.

Table 2. Estimates of Measures of Genetic Variability in Populations of Aedes aegypti from Manaus, Based on Isozymes ${ }^{i}$ and RAPD ${ }^{\mathrm{r}}$ Loci

\begin{tabular}{|c|c|c|c|c|}
\hline \multirow{2}{*}{ Population } & \multirow{2}{*}{ Mean number of samples per locus } & \multirow{2}{*}{ Polymorphic locus percentage* } & \multicolumn{2}{|c|}{ Mean heterozygosity } \\
\hline & & & Observed & Expected $^{* *}$ \\
\hline Coroado & $90.0^{\mathrm{i}}$ & $44.40^{\mathrm{i}}$ & $0.143 \pm 0.05^{\mathrm{i}}$ & $0.164 \pm 0.05^{\mathrm{i}}$ \\
\hline \multirow{2}{*}{ Compensa } & $90.0^{\mathrm{i}}$ & $50.00^{\mathrm{i}}$ & $0.117 \pm 0.04^{\mathrm{i}}$ & $0.131 \pm 0.05^{\mathrm{i}}$ \\
\hline & $28.83^{\mathrm{r}}$ & $86.54^{\mathrm{r}}$ & $0.364^{\mathrm{r}}$ & $0.371^{\mathrm{r}}$ \\
\hline Cidade Nova & $28.60^{\mathrm{r}}$ & $84.61^{\mathrm{r}}$ & $0.350^{\mathrm{r}}$ & $0.356^{\mathrm{r}}$ \\
\hline \multirow{2}{*}{ Praça 14} & $90.0^{\mathrm{i}}$ & $55.60^{\mathrm{i}}$ & $0.152 \pm 0.05^{\mathrm{i}}$ & $0.174 \pm 0.05^{\mathrm{i}}$ \\
\hline & $28.07^{\mathrm{r}}$ & $94.23^{r}$ & $0.387^{\mathrm{r}}$ & $0.394^{\mathrm{r}}$ \\
\hline
\end{tabular}

*Frequency of most common allele less than or equal to 0.95 .

***Hardy-Weinberg expected heterozygosity; unbiased estimate (Nei 1978).

Table 3. Genetic Variation for all Loci in Populations of Aedes aegypti from Manaus, Estimated Using Isozymes and RAPD Markers

\begin{tabular}{|c|c|c|c|c|c|}
\hline Population & Sample Size & $n e^{*}$ & h* & $\mathbf{I}^{*}$ & $\mathbf{P}^{*}$ \\
\hline Coroado & $\begin{array}{l}90^{\mathrm{i}} \\
29^{\mathrm{r}}\end{array}$ & $\begin{array}{l}1.324 \pm 0.474^{\mathrm{i}} \\
1.612 \pm 0.373^{\mathrm{r}}\end{array}$ & $\begin{array}{l}0.163 \pm 0.225^{\mathrm{i}} \\
0.339 \pm 0.183^{\mathrm{r}}\end{array}$ & $\begin{array}{l}0.280 \pm 0.344^{\mathrm{i}} \\
0.492 \pm 0.251^{\mathrm{r}}\end{array}$ & $\begin{array}{l}44.44^{\mathrm{i}} \\
82.69^{\mathrm{r}}\end{array}$ \\
\hline Compensa & $\begin{array}{l}90^{\mathrm{i}} \\
29^{\mathrm{r}}\end{array}$ & $\begin{array}{l}1.222 \pm 0.346^{\mathrm{i}} \\
1.664 \pm 0.353^{\mathrm{r}}\end{array}$ & $\begin{array}{l}0.130 \pm 0.192^{\mathrm{i}} \\
0.364 \pm 0.172^{\mathrm{r}}\end{array}$ & $\begin{array}{l}0.206 \pm 0.287^{\mathrm{i}} \\
0.525 \pm 0.234^{\mathrm{r}}\end{array}$ & $\begin{array}{l}50.00^{\mathrm{i}} \\
86.54^{\mathrm{r}}\end{array}$ \\
\hline Cidade Nova & $\begin{array}{l}90^{\mathrm{i}} \\
29^{\mathrm{r}}\end{array}$ & $\begin{array}{l}1.279 \pm 0.408^{\mathrm{i}} \\
1.624 \pm 0.343^{\mathrm{r}}\end{array}$ & $\begin{array}{l}0.157 \pm 0.209^{\mathrm{i}} \\
0.350 \pm 0.169^{\mathrm{r}}\end{array}$ & $\begin{array}{l}0.248 \pm 0.329^{\mathrm{i}} \\
0.509 \pm 0.232^{\mathrm{r}}\end{array}$ & $\begin{array}{l}44.44^{\mathrm{i}} \\
86.54^{\mathrm{r}}\end{array}$ \\
\hline Praça 14 & $\begin{array}{l}90^{\mathrm{i}} \\
28^{\mathrm{r}}\end{array}$ & $\begin{array}{l}1.324 \pm 0.474^{\mathrm{i}} \\
1.690 \pm 0.283^{\mathrm{r}}\end{array}$ & $\begin{array}{l}0.173 \pm 0.219^{\mathrm{i}} \\
0.387 \pm 0.131^{\mathrm{r}}\end{array}$ & $\begin{array}{l}0.280 \pm 0.344^{\mathrm{i}} \\
0.563 \pm 0.172^{\mathrm{r}}\end{array}$ & $\begin{array}{l}55.56^{\mathrm{i}} \\
94.23^{\mathrm{r}}\end{array}$ \\
\hline Total & $\begin{array}{l}360^{\mathrm{i}} \\
115^{\mathrm{r}}\end{array}$ & $\begin{array}{l}1.293 \pm 0.423^{\mathrm{i}} \\
1.664 \pm 0.324^{\mathrm{r}}\end{array}$ & $\begin{array}{l}0.162 \pm 0.212^{\mathrm{i}} \\
0.372 \pm 0.145^{\mathrm{r}}\end{array}$ & $\begin{array}{l}0.263 \pm 0.329^{\mathrm{i}} \\
0.545 \pm 0.183^{\mathrm{r}}\end{array}$ & $\begin{array}{l}55.56^{\mathrm{i}} \\
96.15^{\mathrm{r}}\end{array}$ \\
\hline \multicolumn{2}{|c|}{$\begin{array}{l}\mathrm{Hs}=0.3600 \pm 0.0212 \\
\mathrm{Ht}=0.3719 \pm 0.0210\end{array}$} & & & & \\
\hline
\end{tabular}

* ne = Effective number of alleles [40]; * $\mathrm{h}=$ gene diversity [41];* I = Shannon's Information index [42]; * $\mathrm{P}=$ Percentage of polymorphic loci; Hs $=$ expected within-population heterozygosity; $\mathrm{Ht}=$ expected total heterozygosity; $\mathrm{i}=$ Isozymes; $\mathrm{r}=\mathrm{RAPD}$. 
Table 4. Analysis of Genetic Structure in Populations of Aedes aegypti from Manaus, using Wright's F Statistics

\begin{tabular}{|c|c|c|c|c|c|c|c|}
\hline \multirow{2}{*}{ Marker } & \multicolumn{4}{|c|}{ POPGENE } & \multicolumn{3}{c|}{ TFPGA } \\
\cline { 2 - 8 } & $\mathbf{F}_{\text {is }}$ & $\mathbf{F}_{\text {it }}$ & $\mathbf{F}_{\text {st }} / \mathbf{G}_{\text {st }}$ & $\mathbf{N}_{\mathbf{m}}$ & $\mathbf{f}$ & $\mathbf{F}$ & $\boldsymbol{\theta}$ \\
\hline \hline Isozymes & 0.164 & 0.198 & 0.041 & $5.827^{*}$ & 0.169 & 0.209 & 0.048 \\
\hline RAPD & & & 0.032 & $15.15^{+}$ & 0.000 & 0.025 & 0.025 \\
\hline
\end{tabular}

$\mathrm{F}_{\mathrm{is}}=$ Inbreeding coefficient among individuals in subpopulations; $\mathrm{F}_{\mathrm{it}}=$ Level of genetic differentiation in the total population; $F_{s t}=$ Level of genetic differentiation among the subpopulations. $\mathrm{G}_{\mathrm{st}}=$ coefficient of genetic differentiation. The inbreeding coefficients $\mathrm{f}$ and $\mathrm{F}$ correspond to Wright's $\mathrm{F}_{\text {is }}$ and $\mathrm{F}_{\mathrm{it}}$, respectively, while theta corresponds to $\mathrm{F}_{\mathrm{st}}$ estimates $[19,20] . *$ Gene flow estimated from $\mathrm{F}_{\mathrm{st}}=0.25\left(1-\mathrm{F}_{\mathrm{st}}\right) / \mathrm{F}_{\mathrm{st}} ;{ }^{\prime} \mathrm{N}_{\mathrm{m}}=0.5(1-$ $\mathrm{G}_{\mathrm{st}} / \mathrm{G}_{\mathrm{st}}[23]$.

of $95 \%$. The population structure was also tested at different hierarchical levels using $\mathrm{F}_{\mathrm{st}}$ by AMOVA analysis for both markers, Isozymes and RAPD. Most of the variation was found within populations $(95.12 \%$ and $99.90 \%$, respectively), indicating a high within-population differentiation (Table 5). The variation among populations was very low ( $4.88 \%$ and $0.10 \%$, respectively). The results suggest that despite the low level of genetic structuring observed in these populations, the gene flow among them is high $\left(\mathrm{N}_{\mathrm{m}}=15.15\right)$. Significant differences among the populations were observed only in the isoenzyme analyses.

Table 5. Hierarchical Analysis of Molecular Variance of Four Aedes aegypti Populations from Manaus, Considering Isozymes ${ }^{\mathrm{i}}$ and RAPD-PCR ${ }^{\mathrm{r}}$

\begin{tabular}{|c|c|c|c|}
\hline Source of Variation & d.f & $\begin{array}{c}\text { \% Variation } \\
\mathbf{F}_{\text {st }}\end{array}$ & $\begin{array}{c}\mathbf{P} \\
\mathbf{F}_{\text {st }}\end{array}$ \\
\hline \hline \multirow{2}{*}{ Among populations } & $3^{\mathrm{i}}$ & $4.88^{\mathrm{i}}$ & $<0.001^{\mathrm{i}}$ \\
& $3^{\mathrm{r}}$ & $0.10^{\mathrm{r}}$ & $>0.05^{\mathrm{r}}$ \\
\hline \multirow{2}{*}{ Within populations } & $716^{\mathrm{i}}$ & $95.12^{\mathrm{i}}$ & $<0.001^{\mathrm{i}}$ \\
& $116^{\mathrm{r}}$ & $99.90^{\mathrm{r}}$ & $>0.05^{\mathrm{r}}$ \\
\hline
\end{tabular}

d.f $=$ degrees of freedom; $\%=$ molecular variance percentage explained by hierarchical level; $\mathrm{P}=$ significance level for hierarchical distribution to be non-random.

The genetic distance values indicate that these populations are genetically very similar (Table 6), from both the

Table 6. Matrix of Genetic Distance and Similarity among the Four Aedes aegypti Populations from Manaus, Based on Isozymes ${ }^{i}$ and RAPD-PCR ${ }^{r}$

\begin{tabular}{|c|c|c|c|c|c|}
\hline & Population & $\mathbf{1}$ & $\mathbf{2}$ & $\mathbf{3}$ & $\mathbf{4}$ \\
\hline \hline 1. & Coroado & $* * * * *$ & $0.987^{\mathrm{i}}$ & $0.993^{\mathrm{i}}$ & $0.997^{\mathrm{i}}$ \\
& & $0.988^{\mathrm{r}}$ & $0.985^{\mathrm{r}}$ \\
\hline 2. & Compensa & $0.013^{\mathrm{i}}$ & & $0.986^{\mathrm{i}}$ & $0.984^{\mathrm{i}}$ \\
& $0.013^{\mathrm{r}}$ & $* * * * *$ & $0.984^{\mathrm{r}}$ & $0.984^{\mathrm{r}}$ \\
\hline 3. & \multirow{2}{*}{ Cidade Nova } & $0.007^{\mathrm{i}}$ & $0.014^{\mathrm{i}}$ & & $0.997^{\mathrm{i}}$ \\
& & $0.012^{\mathrm{r}}$ & $0.016^{\mathrm{r}}$ & $* * * * *$ & $0.985^{\mathrm{r}}$ \\
\hline \multirow{2}{*}{4.} & Praça 14 & $0.003^{\mathrm{i}}$ & $0.016^{\mathrm{i}}$ & $0.003^{\mathrm{i}}$ & \\
& & $0.015^{\mathrm{r}}$ & $0.016^{\mathrm{r}}$ & $0.015^{\mathrm{r}}$ & $* * * * *$ \\
\hline
\end{tabular}

The values above the diagonal correspond to unbiased genetic identity, and those below the diagonal correspond to unbiased genetic distance [26]. data with isozymes and those with RAPD $(\mathrm{D}=0.003-0.016$ and $\mathrm{D}=0.012-0.016$, respectively). Despite the high genetic similarity observed among the populations, it was possible to separate them into three clusters, considering both markers: isozymes (Fig. 3) - Praça 14 and Coroado, and another that separated Cidade Nova from Compensa; RAPD (Fig. 4) Coroado and Cidade Nova which are distinct from Compensa, and another consisting of the population from Praça 14. Likewise, the greatest genetic distance $(0.016)$ for both markers was between Praça 14 and Compensa.
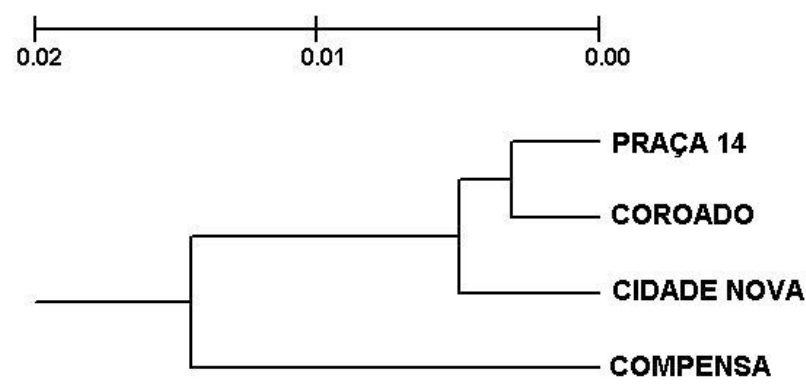

Fig. (3). Dendrogram resulting from grouping among the four Manaus populations of Aedes aegypti, using Isozymes, on the basis of genetic distance [26] by the unweighted pair group method with arithmetic mean - UPGMA, using the TFPGA program [14].

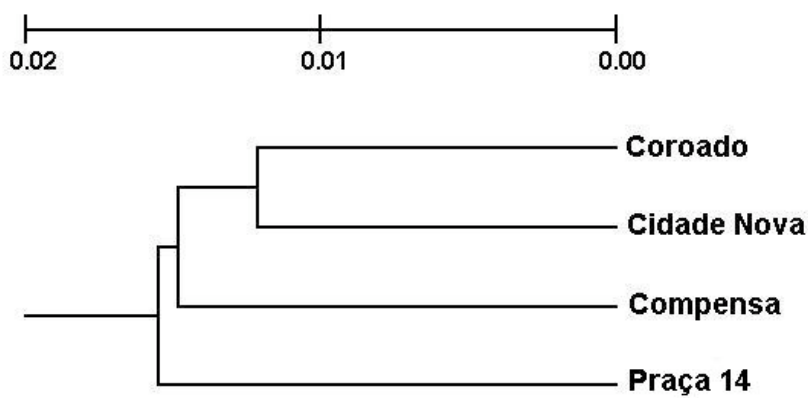

Fig. (4). Dendrogram resulting from grouping among the four Manaus populations of Aedes aegypti, using RAPD, on the basis of genetic distance [26] by the unweighted pair group method with arithmetic mean - UPGMA, based on the TFPGA program [14].

\section{DISCUSSION}

Studies of genetic variability at the molecular level have demonstrated that different regions in the genome have different rates of change. Single-copy genes have relatively low substitution rates because some alteration in a coding sequence may cause a severe effect on the codified protein. Nonetheless, changes in repetitive DNA apparently do not have the same effects, and thus the variability in this genome region is greater than single-copy genes [27]. Although the RAPD technique has limitations, especially to assess genetic relationships beyond the species level, it offers some advantages when applied to studies within the intraspecific level [8]. When RAPD markers were analyzed to estimate the population genetic variability of one species, generally high levels of polymorphism were found, because they offer random polymorphic regions in the genome. Although isozymes are restricted to genes coding for specific proteins, 
they are also useful molecular markers for the study of gene variation.

The analysis of allele frequencies showed that $39 \%$ of the loci were polymorphic in the four populations, using isozymes. Similar results were found in three populations of Guariba, state of São Paulo for Ae. Aegypti [6]. Our results using RAPDs revealed 52 markers, with the percentage of polymorphic loci varying from 82.69 to 94.23 . Heterozygosity ranged from 0.338 in Coroado to 0.387 in Praça 14 . The genetic diversity was significantly higher than the calculated diversity based on isozyme markers $(\mathrm{P}=44.40-$ $55.60 ; \mathrm{Ho}=0.109-0.152)$ for the four populations. The estimated $\mathrm{He}$ was similar to those found in Ae. aegypti populations from Puerto Rico $(\mathrm{He}=0.354)$ [28], Trinidad $(\mathrm{He}=0.390)$ [29], Mexico $(\mathrm{He}=0.339)$ [30], Argentina $(\mathrm{He}=$ $0.350)$ [8], and some populations from Brazil $(\mathrm{He}=0.238)$ [31]. $\mathrm{H}$ values with RAPDs are greater than those obtained with allozymes, because hyper-variable loci are frequently revealed by the RAPD procedure [28].

In this context, RAPD markers have shown genetic differentiation of Ae aegypti populations all over the world [30, 32] and in Brazil [12, 31,33]. Gorrochotegui-Escalante et al. (2000) [30] analyzed populations of Ae. aegypti from ten cities of the Mexican northeast coast, using 60 RAPD polymorphic loci. These authors observed that those populations were isolated by distance and that gene flow only occurred among populations separated by 90 to $250 \mathrm{~km}$. Garcia-Franco et al. (2002) [32], also using these markers, analyzed the genetic variation in 131 loci of $20 \mathrm{Ae}$. aegypti populations from Mexico, where they also observed isolation by distance.

For Brazilian Ae. aegypti, Ayres et al. (2003) [31] analyzed 47 RAPD polymorphic loci in 15 populations from five states, and detected a high level of genetic differentiation, suggesting population structuring. Santos et al. (2003) [33] analyzed populations from different regions of São Paulo, using these markers, and observed that genetic similarity was higher among mosquitoes whose geographic origins were closer. Paduan et al. (2006) [12], studying Ae. aegypti populations from six Brazilian states, also using RAPD markers, detected 21 polymorphic loci with high polymorphism levels, revealing two main groups.

Population genetic structure is a consequence of the mating patterns and the magnitude of gene flow among them, and is expressed mainly by the quantity of differentiation or variation in allelic frequency among the populations [34]. In this context, the $\mathrm{F}_{\text {st }}$ values detected in this study from isozyme markers may indicate the beginning of a geneflow reduction process as well as the occurrence of nonrandom couplings, since the $\mathrm{F}_{\text {is }}$ value was relatively high. Fraga et al. (2003) [5], Dinardo-Miranda \& Contel (1996) [6], Tabachnick \& Wallis (1985) [35], and Failloux et al. (1995) [36], using this marker, reported similar results for the population genetic structure of this mosquito. However, in populations from São Paulo, Dinardo-Miranda \& Contel (1996) [6] found lower values of $F_{\text {is }}>F_{\text {st }}(0.057>0.018)$. In that study, although the $F_{\text {st }}$ value was low, it was significant and indicated slight differentiation among the populations, showing that the variability of allelic frequencies has an intrapopulation origin.
RAPD markers have also given results that indicate population genetic differentiation of this mosquito, as described by Ayres et al. (2003) [31], studying 15 populations of Ae. aegypti from five Brazilian states. They analyzed 47 RAPD polymorphic loci and reported high levels of genetic polymorphism $(\mathrm{Hs}=0.274)$ among the different states $\left(\mathrm{G}_{\mathrm{st}}=0.317\right)$, as well as among cities $\left(\mathrm{G}_{\mathrm{st}}=\right.$ $0.085-0.265)$. Ayres et al. (2003) [31] suggested that this high polymorphism level results from the frequent use of insecticides in areas of treatment for these vectors, which could establish a cycle of extinction and recolonization resulting in genetic differentiation. Similarly, Paduan et al. (2006) [12] detected 21 polymorphic loci with high levels of polymorphism $(\mathrm{Hs}=0.224)$ and high levels of genetic differentiation among populations of Ae. aegypti from those different states $\left(\mathrm{G}_{\mathrm{st}}=0.430\right)$, as well as among populations in cities $\left(\mathrm{G}_{\mathrm{st}}=0.410\right)$, indicating significant differences among populations from the six states. According to Ayres et al. (2003) [31], this high differentiation may reflect important differences in competence, susceptibility to the parasite, and resistance to insecticides, so that populations from different areas of Brazil must be treated as independent epidemiological units.

The differences observed in the estimated $\mathrm{F}_{\mathrm{st}}$ with both types of markers could be the result of differences in the mutation rate of these loci, as suggested by Yan et al. (1999) [29] when they studied populations of Ae. aegypti based on RAPD, AFLP, RFLP, and isozyme markers. They argued that the $\mathrm{F}_{\mathrm{st}}$ value can be seriously underestimated if the loci mutation rates are relatively high. RAPD loci tend to have higher mutation rates than isozyme loci, and therefore the $F_{\text {st }}$ calculated from RAPD markers may be underestimated. On the other hand, the mutation rate of isozyme markers is generally lower than the DNA markers, so a higher $\mathrm{F}_{\mathrm{st}}$ estimate can be expected. According to Slatkin \& Barton (1989) [37], the statistic theta tends to overestimate mutation rates, as was observed with our RAPD data, which showed lower values than with Wright's $\mathrm{F}_{\text {st. }}$

The analysis of molecular variation (Table 5) demonstrated that the majority of the genetic variability is within the populations $(95.12 \%$ for Isoenzymes and $99.90 \%$ for RAPD), although there is a significant difference between the populations when we consider only the isoenzyme analysis $(4.88 \% ; \mathrm{P}<0.0001)$. The data from RAPD were not significant, due largely to the analyses with dominant markers, which consider the allele frequencies of the populations in Hardy-Weinberg equilibrium. The low proportion of interpopulation in relation to intrapopulation variance lends support to the data in Table 4, where the values of $\mathrm{F}_{\mathrm{st}} / \mathrm{G}_{\mathrm{st}}$ and $\mathrm{N}_{\mathrm{m}}$ show a small genetic differentiation, indicating a high migration rate and that the populations still have a metapopulation structure, i.e., there is gene flow among them.

The genetic distance obtained from the square root of gene frequencies varied from 0.0122 to 0.0166 (Table 6), indicating homogeneity among the four populations from Manaus. These results indicate that levels of gene flow between Ae. aegypti populations can be high. Studies based on allozymes [38] and RAPD [28] demonstrated continuous gene flow among Ae. aegypti populations in Puerto Rico that were approximately $100 \mathrm{~km}$ apart. This observation is 
congruent with our estimate using RAPD and Isozyme markers, with which the same genetic distance value was obtained among the populations, which showed great genetic similarity. The high observed genetic diversity as well as other factors may be related to the high dispersion rate of this mosquito, which is favored by dense human populations such as in Manaus (2,000,000 inhabitants) [4]. The consequence is a relatively high gene flow, despite systematic applications of insecticides in dengue control that lead to a reduction in the size of the population, followed by an increase when these measures are relaxed.

These data reflect a low level of genetic differentiation among the Ae. aegypti populations studied. Taking the direct relationship between genetic distances and evolving time into account, it may be inferred that the divergence between populations is fairly recent. They are possibly the result of a single introduction into Manaus, in November 1996 through its high dispersion and adaptive capacity, the species propagated in other districts of the city [4, 39]. The results not only suggest the existence of a single lineage of $\mathrm{Ae}$. aegypti in Manaus, and possibly the same susceptibility for transmitting the dengue and urban yellow-fever viruses, but also their similar responses to control programs.

\section{ACKNOWLEDGEMENTS}

The authors thank the technicians of the Malaria and Dengue Vector Laboratory for technical support in the collections and identification of the mosquitoes. We thank PNOPG, PPI-3680 and PPI-3130 for financial support.

\section{REFERENCES}

[1] Consoli RAGB, Lourenço-de-Oliveira R. Principais Mosquitos de Importância Sanitária no Brasil. Rio de Janeiro: FIOCRUZ 1994.

[2] Honório NA, Lourenço-de-Oliveira R. Freqüência de larvas e pupas de Aedes aegypti e Aedes albopictus em armadilhas, Brasil. Rev Saúde Pública 2001; 35: 385-91.

[3] MS/SVS. Ministério da Saúde/Secretaria de Vigilância em Saúde. Tabela de casos notificados de Dengue. Brasil, Grandes Regiões e Unidades Federadas: 1997 a 2007. Available from: http://portal. saude.gov.br/portal/arquivos/pdf/tabela_dengue2007.pdf. (accessed 10 July 2008).

[4] Pinheiro VCS, Tadei WP. Frequency, diversity, and productivity study on the Aedes aegypti most preferred containers in the city of Manaus, Amazonas, Brazil. Rev Inst Med Trop S Paulo 2002; 44: 245-50.

[5] Fraga EC, Santos JMM, Maia JF. Enzymatic variability in Aedes aegypti (Diptera: Culicidae) populations from Manaus-AM, Brazil. Genet Mol Biol 2003; 26: 181-7.

[6] Dinardo-Miranda LL, Contel EPB. Variability in natural populations of Aedes aegypti (Diptera, Culicidae) from Brazil. J Med Entomol 1996; 33: 726-33.

[7] Sousa GB, Aviles G, Gardenal CN. Allozymic polymorphism in Aedes aegypti populations from Argentina. J Am Mosq Control Assoc 2000; 16: 206-9.

[8] Sousa GB, Blanco A, Gardenal CN. Genetic relationships among Aedes aegypti (Diptera: Culicidae) populations from Argentina using random amplified polymorphic DNA polymerase chain reaction markers. J Med Entomol 2001; 38: 371-5.

[9] Ravel S, Hervé JP, Diarrassouba S, Kone A, Cuny G. Microsatellite markers for population genetic studies in Aedes aegypti (Diptera: Culicidae) from Côte d' Ivoire: evidence for a microgeographic genetic differentiation of mosquitoes from Bouaké. Acta Trop 2002; 82: 39-49.

[10] Costa-da-Silva AL, Capurro ML, Bracco JE. Genetic lineages in the yellow fever mosquito Aedes (Stegomyia) aegypti (Diptera: Culicidae) from Peru. Mem Inst Oswaldo Cruz 2005; 100: 539-44.
[11] Herrera F, Urdaneta L, Rivero J, et al. Population genetic structure of the dengue mosquito Aedes aegypti in Venezuela. Mem Inst Oswaldo Cruz 2006; 101: 625-33.

[12] Paduan KS, Araújo-Júnior JP, Ribolla PEM. Genetic variability in geographical populations of Aedes aegypti (Diptera, Culicidae) in Brazil elucidated by molecular markers. Genet Mol Biol 2006; 29: 391-5.

[13] Bracco JE, Capurro ML, Lourenço-de-Oliveira R, Sallum MA. Genetic variability of Aedes aegypti in the Americas using a mitochondrial gene: evidence of multiple introductions. Mem Inst Oswaldo Cruz 2007; 102: 573-80.

[14] Miller MP. Tools for population genetic analyses (TFPGA): A Windows program for the analysis of allozyme and molecular population genetic data, version 1.3. Department of Biological Sciences, Northern Arizona University, 1997. Available from: http://www.marksgeneticsoftware.net/tfpga.htm.

[15] Santos JMM, Contel EPB, Kerr WE. Biologia de anofelinos amazônicos I - Ciclo biológico, postura e estádios de Anopheles darlingi Root, 1926 (Diptera: Culicidae) da Rodovia Manaus/Boa Vista. Acta Amazonica 1981; 11: 789-97.

[16] Steiner WWM, Joslyn DJ. Electrophoretic techniques for the genetic study of mosquitoes. Mosq News 1979; 39: 35-54.

[17] Lima LMKS, Contel EPB. Electrophoretic analysis of 12 proteins in natural populations of Spodoptera frugiperda (Lepidoptera: Noctuidae). Rev Brasil Genet 1990; 13: 711-29.

[18] Williams JGK, Kubelik AR, Livak KJ, Rafaski J, Tingy SV. DNA polymorphisms amplified by arbitrary primers are use as genetic markers. Nucleic Acids Res 1990; 18: 6531-5.

[19] Weir BS. Genetic Data Analysis: Methods for Discrete Population Genetic Data. Sunderland, Massachusetts, Sinauer Associates Inc. 1990 .

[20] Weir BS. Genetic Data Analysis II: Methods for Discrete Population Genetic Data. Sunderland, Massachusetts, Sinauer Associates Inc. 1996.

[21] Swofford DL, Selander RB. Biosys - 1: A fortran program for the comprehensive analyses of electrophoretic data in population genetics and systematics. J Hered 1981; 72: 281-3.

[22] Yeh FC, Yang R-C, Boyle T. Popgene version 1.32: Microsoft Window-based freeware for population genetic analysis. [updated 2008 August 23]. Available from: http://www.ualberta.ca/ fyeh/.

[23] McDermott JM, McDonald BA. Gene flow in plant pathosystems. Ann Rev Phytopathol 1993; 31: 353-73.

[24] Michalakis Y, Excoffier L. A generic estimation of population subdivision using distances between alleles with special reference for microsatellite loci. Genetics 1996; 142: 1061-4.

[25] Schneider S, Roessli D, Excoffier L. Arlequin ver. 2000: A Software for population genetic data analysis. Genetics and Biometry Laboratory, University of Geneva, Switzerland. [updated 2000 November 17]. Available from: http://cmpg.unibe.ch/ software/arlequin3/

[26] Nei M. Estimation of average heterozygosity and genetic distance from a small number of individuals. Genetics 1978; 89: 583-90.

[27] Li W-H, Graur D. Fundamentals of Molecular Evolution. Sunderland, Massachusetts, Sinauer Associates, 1991.

[28] Apostol BL, Black $4^{\text {th }}$ WC, Reiter P, Miller BR. Population genetics with RAPD-PCR markers: the breeding structure of Aedes aegypti in Puerto Rico. Heredity 1996; 76: 325-34.

[29] Yan G, Romero-Severson J, Walton M, Chadee DD, Severson DW. Population genetics of the yellow fever mosquito in Trinidad: Comparisons of amplified fragment length polymorphism (AFLP) and restriction fragment length polymorphism (RFLP) markers. Mol Ecol 1999; 8: 951-63

[30] Gorrochotegui-Escalante N, Muñoz ML, Fernandez-Salas I, Beaty BJ, Black IV WC. Genetic isolation by distance among Aedes aegypti populations along the northeastern coast of Mexico. Am J Trop Med Hyg 2000; 62: 200-9.

[31] Ayres CFJ, Melo-Santos MAV, Solé-Cava AM, Furtado AF. Genetic differentiation of Aedes aegypti (Diptera, Culicidae), the major dengue vector in Brazil. J Med Entomol 2003; 40: 430-5.

[32] García-Franco F, Muñoz ML, Lozano-Fuentes S, Fernández-Salas I, García-Rejon J, Beaty BJ, Black 4th WC. Large genetic distances among Aedes aegypti populations along the South Pacific coast of Mexico. Am J Trop Med Hyg 2002; 66: 594-8.

[33] Santos VM, Macoris MLG, Andrighetti MTM, Ávila PE, Kirchgatter K. Analysis of genetic relatedness between populations 
of Aedes aegypti from different geographic regions of São Paulo state, Brazil. Rev Inst Med Trop S Paulo 2003; 45: 99-101.

[34] Eanes WF, Koehn RK. An analysis of genetic structure in the monarch butterfly, Danaus plexippus L. Evolution 1978; 32: 78497.

[35] Tabachnick WJ, Wallis GP. Population genetic structure of the yellow fever mosquito Aedes aegypti in the Caribbean: ecological considerations. International Mosquito Ecology Workshop Symposium. Vero Beach, Florida 1985

[36] Failloux AB, Darius H, Pasteur N. Genetic differentiation of Aedes aegypti the vector of dengue in French Polynesia. J Am Mosq Control Assoc 1995; 11: 457-62.

[37] Slatinkin M, Barton NH. A comparison of three indirect methods for estimating average levels of gene flow. Evolution 1989; 43: 1349-68.
[38] Wallis GP, Tabachnick WJ, Powell JR. Genetic heterogeneity among Caribbean populations of Aedes aegypti. Am J Trop Med Hyg 1984; 33: 492-8.

[39] Figueiredo RMP, Thatcher BD, Lima ML, Almeida TC, Alecrim WD, Guerra MVF. Doenças exantemáticas e primeira epidemia de dengue ocorrida em Manaus, Amazonas, no período de 1998-1999. Rev Soc Bras Med Trop 2004; 37: 476-9.

[40] Kimura M, Crow JF. The number of alleles that can be maintained in a finite population. Genetics 1964; 49: 725-38

[41] Nei M. Analysis of gene diversity in subdivided populations. Proc Natl Acad Sci USA 1973; 70: 3321-23.

[42] Lewontin RC. The apportionment of human diversity. In: Dobzhansky T, Hecht MK, Steere WC, Eds. Evolutionary Biology 6. New York, Appleton-Century-Crofts, 1972: 381-98.

Received: December 27, 2010

Revised: February 15, 2011

Accepted: February 22, 2011

(C) dos Santos et al.; Licensee Bentham Open.

This is an open access article licensed under the terms of the Creative Commons Attribution Non-Commercial License (http://creativecommons.org/licenses/bync/3.0/), which permits unrestricted, non-commercial use, distribution and reproduction in any medium, provided the work is properly cited. 